\title{
PEMIKIRAN PENDIDIKAN K.H. AHMAD DAHLAN DAN RELEVANSINYA DENGAN DUNIA PENDIDIKAN MODERN
}

\section{Muhammad Hamsah}

Institut Agama Islam Negeri Salatiga

E-Mail: muhammadhamsah27@yahoo.com

\author{
Nurchamidah \\ Institut Agama Islam Negeri Salatiga \\ E-Mail: idamida676@gmail.com
}

\section{Rasimin}

Institut Agama Islam Negeri Salatiga

E-Mail: rasimin75@gmail.com

\begin{tabular}{|c|c|c|}
\hline Received & Revised & Accepted \\
\hline 4 July 2021 & 2 Agustus 2021 & 20 September 2021 \\
\hline
\end{tabular}

\section{EDUCTION INSIGHT OF KH. AHMADAHLAN AND IT'S RELEVANCE TO MODERN EDUCATION WORLD}

\begin{abstract}
This study aims to explore the insight essence of $\mathrm{KH}$. Ahmad Dahlan and its relevance to the world of modern education as a pioneer of education. The research was qualitatif approach in the form of library research. The collection technique is by documentation, document analysis. The technique of analyzing descriptive data is verification and drawing conclusions. The results of this study are the educational thinking of $\mathrm{KH}$. Ahmad Dahlan combines religious knowledge and general knowledge. Teacher exchange, long life long education, teacher competence, teacher learning program. Social competence, leadership, cosmopolitan open social competence.

Keywords: KH. Ahmad Dahlan insight, modern education, and education innovation.

Abstrak

Penelitian ini bertujuan untuk menelusuri hakikat pemikiran pendidikan KH. Ahmad Dahlan dan relevansinya dengan dunia pendidikan modern sebagai seorang pelopor pendidikan. Jenis penelitian ini yaitu penelitian kualitatif yang berbentuk library research (Penelitian Pustaka). Teknik pengumpulannya yaitu dengan dokumentasi, analisis dokumen. Teknik analisis data deskriptif verifikatif dan penarikan kesimpulan. Adapun hasil dari penelitian ini adalah pemikiran pendidikan $\mathrm{KH}$. Ahmad Dahlan memadukan materi pengetahuan agama dan pengetahuan umum. Pertukaran guru, long life long education, kompetensi guru, program guru pembelajar. Kompetensi sosial, kepemimpinan, kompetensi sosial terbuka kosmopolit.
\end{abstract}

Kata kunci: pemikiran KH. Ahmad Dahlan, pendidikan modern, dan inovasi pendidikan. 


\section{Pendahuluan}

Kedatangan pemerintahan kolonial Belanda sangat mempengaruhi pola pendidikan Islam di Indonesia. Dimana pada masa pemerintah jajahan sekolahsekolah didirikan semata-mata untuk kepentingan penjajah Belanda, yaitu untuk memperoleh tenaga administrasi yang murah sebagai penunjang birokrasi penjajahan, karena tenaga-tenga yang didatangkan dari belanda cukup mahal. Dipihak lain, Belanda memberikan kesempatan yang luas pada misi dan zending agama Kristen untuk mendirikan sekolah-sekolah yang dibiayai oleh gereja. Sedangkan Pendidikan untuk bangsa Indonesia kebanyakan dilakukan di surau dan pondok pesantren yang hanya hanya mengajarkan agama tidak secara komprehensif dan tidak mengejarkan ilmu pengetahuan umum ${ }^{1}$.

Perubahan dalam kehidupan merupakan suatu keniscayaan yang begitu susah dihindari. Padahal dalam perubahan hidup tersebut sejatinya terdapat banyak harapan yang bisa diraih ${ }^{2}$. Termasuk juga dengan kehidupan pendidikan di Indonesia, perubahan yang dilakukan kebanyakan hanya atas dasar reaksi emosional sesaat atau hanya karena meniru sesuatu dari luar yang sebenarnya tidak pas ukurannya dengan situasi dan kondisi pendidikan di Indonesia.

Kalau pun ada, baik perorangan maupun lembaga pendidikan yang jargonnya perubahan, kemajuan atau yang lainnya. Akan tetapi lihat saja aksi yang dilakukannya tetap sama dengan pendahulunya yang waktunya sudah terpaut lama, artinya yang dilakukan bukan aksi pembaharuan tapi romantisme pada debu sejarah tanpa semangat untuk terus menyalakan api semangat pembaharuan ${ }^{3}$. Padahal banyak sekali dinamika-dinamika dalam dunia pendidikan yang membutuhkan pembaharuan karena semakin besarnya tantangan globalisasi.

Adapun faktor pendidikan merupkan faktor yang teramat penting dalam membangun peradaban bangsa. Sehingga dibalik bangsa yang sukses dan maju dilatarbelakangi oleh pendidikan yang bagus juga. Tentunya pendidikan yang dimaksud yaitu pendidikan dengan proses yang amat sangat panjang sehingga dapat membangun peradaban bangsa yang gemilang. Indonesia dalam membangun peradabannya dimulai dari pendidikan yang sangat panjang. Tentunya dengan perjuangan seluruh rakyat dan dipengaruhi oleh para tokohtokoh nasional. Adapun salah satunya yaitu Muhammad Darwis atau yang lebih dikenal dengan K.H. Ahmad Dahlan. Beliau -rahimahullah- merupakan salah satu tokoh pendidikan Islam di bumi nusantara dan merupakan pendiri organisasi Islam bernama organisasi Muhammadiyah. Konsep-konsep K.H. Ahmad Dahlan mengenai pendidikan sangat revolusioner. Dia mengadakan modernisasi dalam bidang pendidikan Islam, dari sistem pondok yang melulu diajar pelajaran pendidikan agama Islam, dari sistem pondok yang melulu diajar secara perseorangan menjadi secara kelas dan ditambah dengan pelajaran pengetahuan umum.

\footnotetext{
${ }^{1}$ Fandi Ahmad, "Pemikiran KH Ahmad Dahlan Tentang Pendidikan Dan Implementasinya Di SMP Muhammadiyah 6 Yogyakarta Tahun 2014/2015," Profetika: Jurnal Studi Islam 16, no. 2 (2015): 144-54.

2 Siti Arofah, "Gagasan Dasar Dan Pemikiran Pendidikan Islam KH Ahmad Dahlan," Tajdida: Jurnal Pemikiran Dan Gerakan Muhammadiyah 13, no. 2 (2016): 114-24.

${ }^{3}$ Leyan Mustapa, "Pembaruan Pendidikan Islam: Studi Atas Teologi Sosial Pemikiran KH Ahmad Dahlan," Jurnal IImiah AL-Jauhari: Jurnal Studi Islam Dan Interdisipliner 2, no. 1 (2017): 90-111.
} 
Untuk itu, penelitian ini diharapkan dapat mencerahkan kembali para pendidik untuk kembali kedalam citacita Muhammadiyah yang sebenarnya. Sehingga dapat terwujudnya cita-cita Muhammadiyah untuk bangsa Indonesia yang diberkahi oleh Allah subhanahu wa ta'ala.

KH. Ahmad Dahlan merupakan seorang pendidik yang benar-benar berjiwa pendidik. ${ }^{4}$ Dalam hal ini sejarah membuktikan bahwa KH. Ahmad Dahlan merupakan tokoh yang sangat konsisten dengan semangat dan aksi pembaharuan. Oleh karena itu, sangat tepat untuk digali pokok-pokok pemikirannya berkenaan pembaharuan dalam bidang pendidikan Islam.

\section{Metode Penelitian}

Penelitian ini menggunakan penelitian kualitatif yang berbentuk library research (penelitian Pustaka). Jenis penelitian deskriptif verifikatif. Teknik pengumpulan data yaitu dengan dokumentasi, analisis dokumen. Teknik analisis data yaitu deskriptif verifikatif dan penarikan kesimpulan. Penelitian ini dilaksanakan untuk menggambarkan dan menjelaskan konsep pendidikan K.H. Ahmad Dahlan dan relevansinya dengan pendidikan modern.

\section{Hasil dan Pembahasan}

\section{Biografi Kehidupan KH. Ahmad Dahlan}

Darah intelektual keulamaan mengalir deras pada diri KH. Ahmad Dahlan, berikut kami uraikan secara singkat riwayat keluarga beliau. KH. Ahmad Dahlan lahir di Kauman, Yogyakarta pada tanggal 1 Agustus 1868 dengan nama kecil Muhammad Darwis. Ibunya bernama Siti Aminah binti KH. Ibrahim, seorang penghulu besar Yogyakarta. Sementara silsilah nasab ayahnya bersambung ke tokoh Walisongo yaitu Maulana Malik Ibrahim dalam urutan ke-12, yaitu KH. Ahmad Dahlan bin KH. Abu Bakar bin KH. Muhammad Sulaiman bin K. Murtadha bin K. Ilyas bin Demang Djurung Djuru Kapindo bin Demang Djurung Djuru Sapisan bin Maulana Sulaiman Ki Ageng Gribing (Djatinom) bin Maulana Muhammad Fadlullah (Sunan Prapen) bin Maulana Ainul Yaqin (Sunan Giri) bin Maulana Ishaq bin Maulana Malik Ibrahim. ${ }^{5}$

\section{Riwayat Pendidikan KH. Ahmad Dahlan}

Semenjak kecil beliau mengawali pendidikannya dengan belajar Al-Qur'an kepada ayahnya. Setelah tamat beliau meneruskan pendidikannya dengan belajar berbagai konsentrasi keilmuan kepada beberapa orang kyai baik yang berada di dalam maupun di luar negeri. Di dalam negeri beliau belajar fiqh pada $\mathrm{KH}$. Muhammad Shaleh, belajar nahwu kepada KH. Muhsin, berguru ilmu hadis pada K. Mahfudh Termas dan Syaikh Khayat, belajar Qiraah pada Syaikh Amien dan Sayyid Bakri Syatha, belajar falaq kepada KH. Dahlan Semarang, dan belajar ilmu racun binatang kepada Syaikh Hasan. Sementara itu, pengalaman juga beliau dapatkan

\footnotetext{
${ }^{4}$ GRAy, Koes Moertiyah, Satu Abad Muhammadiyah: Tafsir Jawa Keteladanan KIAI Ahmad Dahlan, (Yogyakarta: Adiwacana, 2013), hlm. Vii.

${ }^{5}$ Mochammad Ali Shodiqin, Muhammadiyah itu NU: Dokumen Fiqh yang Terlupakan, (Yogyakarta: Noura Books, 2013), hlm. 34.
} 
selama menunaikan ibadah haji pada tahun 1889 dan 1903. Saat berhaji beliau belajar fiqh kepada Syaikh Salaf Bafadal, Syaikh Sa’id Yamani, serta Syaikh Sa’id Babusyel. Belajar ilmu hadis pada Mufti Syafi'i, dan belajar ilmu qira'at pada Syaikh Ali Misri Makkah.

Dari penjabaran tersebut jelas bahwa beliau tidak punya pengalaman pendidikan Barat, tapi beliau tetap memberi ruang bagi gerbang rasionalitas dalam ajaran Islam. Semangat rasionalitas ini tidak bisa lepas dari pengaruh gerakan pembaharuan yang dipahami sebagai pikiran, aliran, gerakan dan usaha "mengubah" ajaran-ajaran yang terdapat dalam agama untuk disesuaikan dengan konteks baru yang ditimbulkan oleh kemajuan iptek. ${ }^{6}$ Gerakan ini berlangsung di Timur Tengah dengan diprakarsai oleh Djamaluddin Al-Afghanni, Muhammad Abduh dan Rasyid Ridha. Juga dipengaruhi konten bacaan yang dimuat dalam tafsir Al-Manar milik perpustakaan Jami'at Khair yang diperoleh dari hasil penyelundupan di pelabuhan Tuban, Jawa Timur. ${ }^{7}$

\section{Taraf Pendidikan Masyarakat Sekitar KH. Ahmad Dahlan}

Berbicara mengenai taraf pendidikan masyarakat yang melingkupi perjalanan hidup KH. Ahmad Dahlan terdapat dua hal yang cukup serius untuk dicermati.

a. Berkenaan dengan akses pedidikan. Kebijakan politik etis atau balas budi yang dilaksanakan pemerintah kolonial pada dekade pertama abad XX memang terfokuskan pada bidang pendidikan. Akan tetapi, kesempatan untuk mengakses pendidikan secara merata hanya dibatasi pada jenjang pendidikan rendah saja, sementara pendidikan menengah dan tinggi masih terbatas diperuntukkan bagi kelompok elit pribumi saja. Kebijakan ini ditetapkan dengan dikeluarkannya UU Pendidikan Bumiputera pertama pada tanggal 3 Mei 1871 yang menyatakan sasaran pendidikan itu adalah aan de kinderen van inlandsche hoofdrn, alsmede verdere inlandsche bevolking. ${ }^{8}$ Lulusannya pun hanya dijadikan sebagai birokrat pribumi antek-antek Belanda.

b. Berkenaan dengan konten pendidikan. Terdapat dikotomi keilmuan, lembaga pendidikan pemerintah hanya mengajarkan "ilmu umum" saja dan pesantren hanya "ilmu agama" saja. Dalam intern Islam ilmu praktis seperti ekonomi, politik, kebudayaan, pertanian dan sejenisnya dianggap bukan "ilmu agama”, tapi "ilmu kafir". Oleh karena itu, kesimpulannya bahwa pendidikan yang ada belum seutuhnya memenuhi kebutuhan hidup sehari-hari.

\footnotetext{
${ }^{6}$ Harun Nasution, Pembaharuan dalam Islam: Sejarah Pemikiran dan Gerakan, (Jakarta: Bulan Bintang, 2003), hlm. 3-4.

${ }^{7}$ Muhammad Damami, Akar Gerakan Muhammadiyah, (Yogyakarta: Fajar Pustaka Baru, 2000), hlm. 83.

${ }^{8}$ Oarakitri T. Simbolon, Menjadi Indonesia, (Jakarta: Kompas, 2006), hlm. 213.
}

Risâlah, Jurnal Pendidikan dan Studi Islam https://jurnal.faiunwir.ac.id/index.php/Jurnal_ Risalah 


\section{Kehidupan Keagamaan Masyarakat Sekitar KH. Ahmad Dahlan}

Jauh sebelum kelahiran KH. Ahmad Dahlan keadaan umat Islam Indonesia sudah kental dengan Islam sinkretis. Sekalipun tidak bisa dipungkiri bahwa peningkatan jumlah penganut Islam karena hasil dari proses akulturasi antara Islam dan budaya, akan tetapi efek umat yang terkristalisasi dengan kebiasaan irasionalitas dari beberapa sisi sikap sinkretis akan menurunkan kualitas umat Islam. Mereka terbiasa dipaksa tunduk patuh tanpa sikap kritis sehingga mudah ditindas dan dijajah karena tidak punya semangat untuk kebebasan.

\section{Situasi Politik Masa KH. Ahmad Dahlan}

Situasi politik masa perjuangan pembaharuan KH. Ahmad Dahlan berada pada fase ketika dunia Islam yang direpresentasikan oleh kekuasaan imperium Turki Usmani mengalami goncangan dan kondisi nusantara sedang dalam keadaan dicengkram pemerintahan kolonialisme Hindia Belanda yang sangat diskriminatif terhadap umat Islam. Struktur yuridis formal masyarakat kolonialis secara tegas membedakan kelompok masyarakat berdasarkan suku bangsa. Dalam stratifikasi kolonial, masayarakat pribumi yang notabene kebayakan adalah orang-orang Islam ditempatkan pada posisi yang paling rendah di bawah orang Eropa, di bawah orang China, di bawah orang jepang, di bawah orang Arab, dan bahkan di bawah orang India. ${ }^{9}$

Dalam melakukan usaha pembaharuan KH. Ahmad Dahlan menggunakan organisasi Muhammadiyah sebagai sarananya. Persyarikatan ini didirikan KH. Ahmad Dahlan pada 18 November 1912 atau 8 Dzulhijjah 1330 dan resmi keluar badan hukumnya pada tahun 1914 saat dimulainya perang dunia I. Perang dunia I diikuti oleh blok sekutu (Inggris, Perancis dan Rusia) dan blok poros (Jerman, Austria dan Hongaria). Sementara Belanda sebagai pemerintah kolonial di Indonesia bersikap netral. Namun belakangan Ratu Wilhelmia menunjukkan sikap tidak senang dengan Inggris. Investasi bisnis Jerman yang sangat besar di Belanda memaksa Inggris memblokade pelabuhan Belanda untuk melemahkan kekuatan blok poros. Akibatnya Belanda merugi karena kapal dagangnya banyak yang terkena torpedo.

Selanjutnya keadaan dunia menjadi kacau, pengangguran meningkat, pabrik-pabrik ditutup, pasar dunia terpuruk, bahkan terjadi kelangkaan pangan. Akibatnya, Turki Usmani yang awalnya netralpun kemudian juga berubah sikap bergabung ke blok poros. Keadaan demikian membuat Inggris berkesempatan untuk meruntuhkan dinasti pemegang jabatan khalifah itu sekaligus merebut tanahnya. Kampanye anti Turki meluas, Inggris pun mendapat banyak sekutu seperti Ibnu Saud di Najd bersama kaum Wahabinya, kaum pembaharu sekuler Turki Muda, Syarif Husein di Hijaz dan Zionis Zahudi. Meskipun di antara mereka kepentingannya saling

\footnotetext{
${ }^{9}$ Majelis Diklitbang dan LPI PP Muhammadiyah, 1 Abad Muhammadiyah: Gagasan Pembaruan Sosial Keagamaan, (Jakarta: Kompas, 2010), hlm. 10.
} 
berseberangan tapi semua sama dalam hal melawan Turki Usmani dengan harapan bisa menguasai tanahnya.

Singkatnya cerita, Turki Usmani yang sebelumnya mampu berjaya di tiga benua, Asia, Eropa dan Afrika selama 600 tahun sejak 1299 harus menghadapi Revolusi Arab yang dimotori Inggris berikut sekutu-sekutunya seperti disebut di atas ples campur tangan AS yang bergabung membela sekutu pada tahun 1917. Inilah faktor eksternal yang menyebabkan hancurnya kerajaan Turki Usmani. ${ }^{10}$ Sekaligus ini juga menjadi dorongan dari dalam tubuh Islam untuk bergerak memanfaatkan momen melakukan pembaharuan.

Sejalan dengan hal itu, untuk konteks Indonesia, pemerintah yang bercokol yakni kolonial Hindia Belanda di negara asalnya selain sedang mengalami efek perang seperti disebutkan di atas juga sedang dihadapkan pada meluasnya pengaruh kaum Sosialis Demokrat yang mengancam monarki dinastinya. Begitu juga di tanah jajahannya Indonesia, ISDV yang kelak menjadi PKI telah diresmikan pendiriannya pada tahun 1914. Inilah krisis dan ancaman yang dialami Belanda yang menyebabkan kekhawatiran akan lepasnya tanah jajahan Indonesia yang berarti pula hilanglah tambang emasnya. Situasi demikian dengan cermat dipahami oleh KH. Ahmad Dahlan sebagai sebuah bergaining untuk mendapatkan badan hukum bagi Muhammadiyah sebagai sarana pembaharuannya yang tertata dengan rapi dan tertib. Akhirnya legitimasi tersebut benar beliau dapatkan pada 22 Agustus 1914. ${ }^{11}$

\section{Kondisi Perekonomian Masa KH. Ahmad Dahlan}

Pada masa KH. Ahmad Dahlan diberlakukan kebijakan ekonomi liberal yang sudah lama berlangsung sejak tahun 1870. Adanya kebijakan ini memberikan kesempatan pada pemerintah kolonial sekaligus pihak swasta asing untuk mengeksploitasi sumber-sumber ekonomi Indonesia. Tidak bisa dipungkiri bahwa kebijakan tersebut membuahkan hasil peningkatan infrastruktur dan kesempatan ekonomi baru yang tentunya mempunyai dampak positif terhadap penduduk pribumi. Tapi di sisi lain tekanan ekonomi juga semakin berat akibat kenaikan biaya hidup, penarikan pajak tunai, nilai pendapatan riel yang rendah, maupun petani yang teralienasi dari tanah sebagi faktor produksi utamanya sehingga kehidupan masyarakat pribumi semakin sengsara di banyak tempat. ${ }^{12}$

\footnotetext{
${ }^{10}$ Maman A. Malik, dkk., PengantarSejarah Kebidayaan Islam, (Yogyakarta: Pokja Akademik UIN Sunan Kalijaga Yogyalarta, 2005), hlm. 154.

${ }^{11}$ Mochammad Ali Shodiqin, Muhammadiyah Itu NU: Dokumen Fiqh yang Terlupakan, (Yogyakarta: Noura Books, 2013), hlm. 40-41.

${ }^{12}$ Majelis Diklitbang dan LPI PP Muhammadiyah, 1 Abad..., hlm. 8-9.
} 


\section{Pemikiran-pemikiran KH. Ahmad Dahlan}

1. Bagi Ahmad Dahlan, pembaruan dalam Islam yaitu merealisasikan ajaran Islam dalam praktek kehidupan sosial. ${ }^{13}$

2. Kemudian KH. Ahmad Dahlan meletakkan dasar pemikirannya digerakan Muhammadiyah yaitu semangat tarjih dan tajdid (pembaruan). ${ }^{14}$ Pergerakan Muhammadiyah dalam lintasan satu abad merupakan perwujudan dari pembaruan (tajdid) Kyai Ahmad Dahlan. ${ }^{15}$ Ahmad Dahlan melakukan pembacaan gejala sosial di tengah masyarakat. ${ }^{16}$ Tarjih yaitu suatu pendekatan dalam pemberian fatwa terhadap masalah-masalah yang berkaitan erat dengan akidah Islamiyah, ibadah, dan mu'amalah. ${ }^{17}$

3. "Ijtihad" Petani: Pribumisasi Islam Murni. Ijtihad merupakan pembaruan, yang beriorentasi pada kemajuan, peradaban. Bagi Ahmad Dahlan dan Muhammadiyah, memajukan peradaban langkah awalnya memberantas bid'ah dalam akidah, misalnya ketergantungan masyarakat awalnya pada supranatural utamanya dalam masyarakat petani. Demikian akan menghambat kemajuan. ${ }^{18}$

4. Watak dasar pemikiran Ahmad Dahlan dalam Muhammadiyah sebagai gerakan pembaru atau pemurnian ajaran Islam. Mempelopori pemberantasan TBKh (Takhayul, Bid'ah, dan Khurafat), mempelopori pendidikan Islam modern melalui bangku sekolah. Pertama kali memperkenalkan khutbah jumat dalam Bahasa Indonesia, ied di lapangan terbuka, dan pemakaian Bahasa Indonesia dalam rapat-rapatnya. ${ }^{19}$

5. Melihat keadaan yang serba memperihatinkan seperti penulis uraikan di atas, KH. Ahmad Dahlan terpanggil untuk mengatasinya dengan jalan mengangkat sisi profetik Islam berupa langkah ijtihad. Berikut adalah ijtihad-ijtihad beliau yang di dalamnya terkandung semangat pemikiranpemikiran pembaharuan.

a. Sepulang dari mendatangi Observatorium Lembang untuk membuktikan ilmu yang diperolehnya tentang hisab ${ }^{20}$, beliau mengadakan pertemuan ulama dalam kawasan Yogyakarta mengenai pengakuratan arah kiblat dari semula lurus ke barat menjadi dicondongkan ke arah barat laut $22^{\circ}$.

b. Tahun 1919 berhasil mendirikan Hooge School Kweek School Muhammadiyah yang dalam kurikulum pendidikannya memadukan

\footnotetext{
${ }^{13}$ Abdul Munir Mulkhan, Kiai Ahmad Dahlan: Jejak Pembaruan Sosial dan Kemanusiaan, (Cet. I; Jakarta: Kompas, 2010), hlm. 2.

${ }^{14}$ Hamdan Hambali, Ideologi Dan Strategi Muhammadiyah, (Cet. IV; Yogyakarta: Suara Muhammadiyah, 2008), .h. ix.

${ }^{15}$ Berita Resmi Muhammadiyah: Tanfidz Keputusan Muktamar Satu Abad Muhammadiyah ke 46, (Cet. IV; Yogyakarta: Percetakan Muhammadiyah, 2010), .h. 17.

${ }^{16}$ FajlurRahman Jurdi, Aib Politik Muhammadiyah, (Cet. I; Yogyakarta: Juxtapose, 2007), .h. 107.

${ }^{17}$ Siti Chamamah Soeratno, dkk. Muhammadiyah Sebagai Gerakan Seni dan Budaya: Suatu Warisan Intelektual yang Terlupakan, (Cet. I; Yogyakarta: Pustaka Pelajar, 2009), hlm. 32.

${ }^{18}$ Abdul Munir Mulkhan, Marhaenis Muhammadiyah, (Cet. I; Yogyakarta: Galangpress, 2010), .h. 249-267.

${ }^{19}$ Suwarno, Muhammadiyah Sebagai Oposisi, (Cet. I; Yogyakarta: UII Press Jogjakarta, 2001), .h. xi

${ }^{20}$ Zuhairini, dkk. Sejaran Pendidikan Islam, (Jakarta: Bumi Aksara, 2011), hlm. 199.
} 
antara muatan materi "pengetahuan agama" dengan materi "pengetahuan umum. ${ }^{21}$

c. Mengadakan pertukaran guru dari Kweekschool untuk mengajar di Hooge School Kweek School Muhammadiyah yang beliau dirikan. ${ }^{22}$

d. Mewasiatkan prinsip keguruan "dadio guru lan murid" yang maknanya adalah bahwa seorang guru itu harus selalu berusaha menyebarluaskan ilmunya sekaligus selalu terbuka untuk bersedia mengambil hikmah ke dan dari siapa pun, kapan pun dan di mana pun.

e. Pada waktu mendirikan Sekolah Rakyat Muhammadiyah di Suronatan mengalami kekurangan biaya. Kemudian KH. Ahmad Dahlan merelakan barang-barang rumah tangganya dilelang guna meneruskan pendirian sekolah tersebut. Hasil lelang mencapai F 4.ooo (empat ribu gulden), F 6o (enam puluh gulden) beliau ambil untuk memenuhi kebutuhan pribadi sementara seluruh sisanya beliau berikan untuk kegiatan organisasi. ${ }^{23}$ Inilah contoh nyata dari pesan yang beliau sampaikan di kemudian hari berkenaan dengan peringatan agar hendaknya warga Muhammadiyah tidak mencari kehidupan dalam persyarikatan Muhammadiyah, tetapi senantiasa menghidup-hidupkan Muhammadiyah. ${ }^{24}$

f. Pada tahun 1896 ayah KH. Ahmad Dahlan yang berkedudukan sebagai Ketib Amin meninggal dunia dan beliau diangkat sebagai penggantinya. Dalam posisi ini beliau mau menerima gaji sebesar $\mathrm{F} 7$ (tujuh gulden) per bulan dari sultan. ${ }^{25}$

g. Bersedia mengajar agama di Kweekschool Jetis yang memiliki ruang belajar berupa kelas model Belanda. Selanjutnya karena waktu yang disediakan di sekolah tersebut terbatas, sementara banyak siswa yang tertarik untuk mendalami agama maka beliau membuka kelas di ruang tamu rumahnya yang berukuran 2,5 X $6 \mathrm{M}$ yang didesain seperti ruang kelas ala Belanda yang dilengkapi meja, kursi panjang dan papan tulis agar anak-anak nyaman.

h. Menggunakan metode pertanyaan dalam mengajar (menafsirkan qur'an), mulai dari bagaimana artinya? Bagaimana tafsir atau keterangannya? Bagaimana maksudnya? Apa ini larangan? Apakah sudah meninggalkan larangan? Apakah ini perintah yang wajib dikerjakan? Apakah sudah mengerjakan? ${ }^{26}$

i. KH. Ahmad Dahlan menyelenggarakan pendidikan khusus anak jalanan dan gelandangan yang dikenal dengan sebutan Fathul Asror Miftahus Sa'adah (FAMS). Pembelajarannya mirip yang dikembangkan Paulo Freire

${ }^{21} \mathrm{M}$ Yususf Amin Nugroho, "Fiqh Al-Ikhtilaf NU-Muhammadiyah" (e-Book), (Wonosobo: tanpa penerbit, 2012), hlm. 23.

${ }^{22}$ Zuhairini, dkk. Sejaran Pendidikan..., hlm. 201.

${ }^{23}$ Muhammad Damami, Akar Gerakan..., hlm. 88.

${ }^{24}$ Nasruddin Anshoriy Ch, Matahari Pembaruan, (Yogyakarta: Jogja Bakti Publisher, 2010), hlm. 161.

\footnotetext{
${ }^{25}$ Mochammad Ali Shodiqin, Muhammadiyah Itu..., hlm. 36.
}

${ }^{26}$ Mihammad Damami, Akar Gerakan..., hlm. 91. 
yaitu melalui problematisasi atau penyadaran akan keadaan diri untuk berubah.

j. Mempraktikkan salah satu amal usaha dari al-Ma'un yang diwujudkan melalui pendirian rumah sakit yang diberi label PKO(U) (Penolong Kesengsaraan Oemoem/Umum). Label PKO mencerminkan misi lembaga ini yang terbuka bagi siapa saja yang menderita, tertindas, sakit, miskin dan terbelakang. Di RSPKU Yogyakarta, PKU yang pertama, para dokter yang praktik terdiri dari beragam suku bangsa dan agama, begitu juga dengan pasien yang berobat.

k. Penyandang dana PKU juga berasal dari beragam bangsa dan pemeluk agama. Mereka inilah yang dalam anggaran dasar pertama disebut sebagai anggota luar biasa dan anggota istimewa. ${ }^{27}$

1. KH. Ahmad Dahlan bergaul secara terbuka mulai dari orang biasa, kyaikyai, priyayi-priyayi, para bangsawan, sampai para pendeta. Pastor Katolik Van Dress dan Van Lieth, pendeta Kristen Domine Baker, serta misionaris kristen dari Beirut Dr. Zwemmer beliau pergauli dengan baik. Praktik ini didasari dengan pemikiran persaudaraan kemanusiaan walaupun beda agama. Logika tauhidnya karena nenek moyang manusia beliau yakini hanya satu, yakni adam dan hawa. ${ }^{28}$

m. KH. Ahmad Dahlan terkesan dengan Jevansche Padvinders Organisatie (JPO) milik Mangkunegaran, sehingga mendorongnya membentuk Padvinders Muhammadiyah pada 1918 yang kemudian asal usul Hajid diganti namanya menjadi Hizbul Wathan. ${ }^{29}$

n. Dalam internal umat Islam, KH. Ahmad Dahlan mencanangkan agar masyarakat untuk membersihkan diri dari pengaruh animisme, takhayul, bid'ah dan kufarat yang mengotori akidah. ${ }^{30}$

o. Pada siang hari KH. Ahmad Dahlan memeberikan pelajaran untuk anakanak laki-laki dan perempuan, malam hari untuk remaja dan dewasa.

p. KH. Ahmad Dahlan mengadakan pertemuan tahunan yang disebut sebagai algemeene vergadering untuk menentukan kebijakan organisasi. ${ }^{31}$

6. Pemikiran dan gerakan Ahmad Dahlan dalam Organisasi Muhammadiyah cenderung berbeda dari gerakan Islam lainnya baik di dalam negeri begitu pun di negara lain di zamannya. Ahmad Dahlan bergerak dan berdakwah melalui pendidikan, kegiatan sosial, dan kesehatan. ${ }^{32}$

\footnotetext{
${ }^{27}$ Majelis Diklitbang dan LPI PP Muhammadiyah, 1 Abad..., hlm. XL.

${ }^{28}$ Muhammad Damami, Akar Gerakan..., hlm. 98.

${ }^{29}$ Zuhairini, dkk. Sejaran Pendidikan..., hlm. 176.

${ }^{30}$ Umar Hasyim, Muhammadiyah Jalan..., hlm. 1.

${ }^{31}$ Majelis Diklitbang dan LPI PP Muhammadiyah, 1 Abad... hlm. 76.

${ }^{32}$ Nur Achmad \& Pramono U. Tanthowi, ed, Muhammadiyah Digugat, (Cet. I; Jakarta: PT Gramedia, 2000), .h. 189.
} 


\section{Analisis Relevansi Pemikian KH. Ahmad Dahlan bagi Pendidikan Modern}

Berbicara dalam konteks dunia pendidikan modern Indonesia tidak bisa lepas dari topik tentang Standar Nasional Pendidikan (SNP). Karena hanya dengan memenuhi kriteria-kriteria dalam SNP inilah suatu lembaga pendidikan tidak dikatakan abal-abal. Oleh karena itu, SNP dijadikan pisau dalam menganalisis relevansi pemikiran-pemikiran KH. Ahmad Dahlan bagi dunia pendidikan modern.

\begin{tabular}{|c|c|c|c|}
\hline No & Unsur SNP & $\begin{array}{c}\text { Pemikiran } \\
\text { KH. Ahmad Dahlan }\end{array}$ & Analisis \\
\hline 1 & Standar isi & $\begin{array}{l}\text { Memadukan materi } \\
\text { pengetahuan agama dan } \\
\text { pengetahuan umum di Hooge } \\
\text { School Kweek School } \\
\text { Muhammadiyah }\end{array}$ & Non dikotomis integrasi \\
\hline 2 & Standar proses & $\begin{array}{l}\text { Menggunakan metode } \\
\text { pertanyaan dalam mengajar } \\
\text { (menafsirkan qur'an), } \\
\text { menyelenggarakan pendidikan } \\
\text { khusus anak jalanan dan } \\
\text { gelandangan yang dikenal } \\
\text { dengan Fathul Asror Miftahus } \\
\text { Sa'adah (FAMS). } \\
\text { Pembelajarannya mirip yang } \\
\text { dikembangkan Pulo Freire yaitu } \\
\text { melalui problematisasi atau } \\
\text { penyadaran akan keadaan diri } \\
\text { untuk berubah. }\end{array}$ & $\begin{array}{l}\text { MENGEMBANGKAN } \text { ACTIF } \\
\text { LERNING BAKAT MINAT } \\
\text { ANAK } \\
\text { Pendidikan kritis }\end{array}$ \\
\hline 3 & $\begin{array}{l}\text { Standar } \\
\text { kompetensi } \\
\text { lulusan }\end{array}$ & $\begin{array}{l}\text { Dalam internal Islam, KH. } \\
\text { Ahmad Dahlan mencanangkan } \\
\text { untuk membersihkan diri dari } \\
\text { pengaruh animisme yang } \\
\text { mengotori akidah }\end{array}$ & Kecerdasan spiritual \\
\hline 4 & $\begin{array}{l}\text { Standar } \\
\text { pendidikan } \\
\text { dan tenaga } \\
\text { kependidikan }\end{array}$ & $\begin{array}{l}\text { Mengadakan pertukaran guru } \\
\text { dari Kweekschool untuk } \\
\text { mengajar di Hooge School } \\
\text { Kweek School Muhammadiyah } \\
\text { yang beliau dirikan "dadio guru } \\
\text { lan murid". } \\
\text { Kemudian beliau mengikhlaskan } \\
\text { barang-barang rumah tangga } \\
\text { beliau untuk dilelang guna } \\
\text { meneruskan pendirian sekolah } \\
\text { tersebut. Hasil lelang mencapai } \\
\text { F 4.ooo (empat ribu gulden), F } \\
\text { 6o beliau ambil untuk } \\
\text { memenuhi kebutuhan } \\
\text { pribadinya sementara seluruh } \\
\text { sisanya beliau berikan untuk }\end{array}$ & $\begin{array}{l}\text { PERTUKARAN GURU } \\
\text { Long life long education, } \\
\text { kompetensi guru, program } \\
\text { guru pembelajar. Kompetensi } \\
\text { sosial, } \\
\text { Kompetensi } \\
\text { Kosmopemimpinan. } \\
\text { Kosmolit. }\end{array}$ \\
\hline
\end{tabular}




\begin{tabular}{|c|c|c|c|}
\hline & & $\begin{array}{l}\text { kegiatan Muhammadiyah. } \\
\text { KH. Ahmad Dahlan bergaul } \\
\text { secara terbuka mulai dari orang } \\
\text { bisa, kyai-kyai, priyayi-priyayi, } \\
\text { para bangsawan, sampai para } \\
\text { pen }\end{array}$ & \\
\hline 5 & $\begin{array}{l}\text { Standar sarana } \\
\text { dan prasarana }\end{array}$ & $\begin{array}{l}\text {-Kiblat kompas } \\
\text {-Bersedia mengajar agama di } \\
\text { Kweekschool Jetis yang memiliki } \\
\text { ruang belajar berupa kelas } \\
\text { model Belanda. Selanjutnya } \\
\text { karena waktu yang disediakan di } \\
\text { sekolah tersebut terbatas, } \\
\text { sementara banyak siswa yang } \\
\text { tertarik untuk mendalami } \\
\text { agama maka beliau membuka } \\
\text { kelas di ruang tamu rumahnya } \\
\text { yang berukuran } 2,5 \mathrm{X} 6 \mathrm{M} \text { yang } \\
\text { didesain seperti ruang kelas ala } \\
\text { Belanda yang dilengkapi meja, } \\
\text { kursi panjang dan papan tulis }\end{array}$ & $\begin{array}{l}\text { (Implikasi : penggunaaan } \\
\text { alat modern, percobaan } \\
\text { pembuktian tidak ada alat } \\
\text { yang kafir atau islam, tapi } \\
\text { man behind the gun) } \\
\text { Tidak ada sarana yang kafir, } \\
\text { man behind the gun }\end{array}$ \\
\hline 6 & $\begin{array}{l}\text { Standar } \\
\text { pengelolaan }\end{array}$ & $\begin{array}{l}\text { Label PKO mencerminkan misi } \\
\text { lembaga ini yang terbuka bagi } \\
\text { siapa saja yang menderita, } \\
\text { tertindas, sakit, miskin dan } \\
\text { terbelakang. Di RSPKU } \\
\text { Yogyakarta, PKU yang pertama, } \\
\text { para dokter yang praktik terdiri } \\
\text { dari beragam suku bangsa dan } \\
\text { agama, begitu juga dengan } \\
\text { pasien yang berobat. } \\
\text { KH. Ahmad Dahlan terkesan } \\
\text { dengan Jevansche Padvinders } \\
\text { Organisatie (JPO) milik } \\
\text { Mangkunegaran, sehingga } \\
\text { mendorongnya membentuk } \\
\text { Padvinders Muhammadiyah } \\
\text { pada 1918 yang kemudian asal } \\
\text { usul Hajid diganti namanya } \\
\text { menjadi Hizbul Wathan } \\
\text {-Pada siang hari KH. Ahmad } \\
\text { Dahlan memeberikan } \\
\text { pelajaran untuk anak-anak } \\
\text { laki-laki dan perempuan, } \\
\text { malam hari untuk remaja dan } \\
\text { dewasa. }\end{array}$ & $\begin{array}{l}\text { Lembaga inklusif, terbuka } \\
\text { baik dari segi apa pun } \\
\text { penjadwalan }\end{array}$ \\
\hline 7 & $\begin{array}{l}\text { Standar } \\
\text { pembiayaan }\end{array}$ & $\begin{array}{l}\text { Ketib Amin meninggal dunia } \\
\text { dan beliau diangkat sebagai } \\
\text { penggantinya. Dalam posisi ini }\end{array}$ & $\begin{array}{l}\text { Ikhlas tapi tetap profesional } \\
\text { yang dalam pandangan } \\
\text { kekinian ada penghasilan }\end{array}$ \\
\hline
\end{tabular}




\begin{tabular}{|c|l|l|l|}
\hline & $\begin{array}{l}\text { beliau mau menerima gaji } \\
\text { sebesar F 7 (tujuh gulden) per } \\
\text { bulan. } \\
\text { Penyandang dana PKU juga } \\
\text { berasal dari beragam bangsa dan } \\
\text { pemeluk agama. Mereka inilah } \\
\text { yang dalam anggaran dasar } \\
\text { pertama disebut sebagai anggota } \\
\text { luar biasa dan anggota istimewa }\end{array}$ & FUBSIDI \\
FILANTROPI \\
\hline 8 & $\begin{array}{l}\text { KH. Ahmad Dahlan } \\
\text { Standar } \\
\text { penilaian } \\
\text { tahunan yang disebut sebagai } \\
\text { algemeene vergadering untuk } \\
\text { menentukan kebijakan } \\
\text { organisasi }\end{array}$ & \\
\hline
\end{tabular}

\section{Simpulan}

Pemikiran dan gerakan K.H. Ahmad Dahlan dalam Organisasi Muhammadiyah cenderung berbeda dari gerakan Islam lain, baik di dalam negeri begitu pun di negara lain di zamannya. K.H. Ahmad Dahlan bergerak dan berdakwah melalui pendidikan, kegiatan sosial, dan kesehatan. Berbicara dalam konteks dunia pendidikan modern Indonesia tidak bisa lepas dari topik tentang Standar Nasional Pendidikan (SNP). Karena hanya dengan memenuhi kriteriakriteria dalam SNP inilah suatu lembaga pendidikan dikatakan berkualitas. Oleh karena itu, SNP dijadikan pisau analisis dalam menganalisis relevansi pemikiranpemikiran KH. Ahmad Dahlan bagi dunia pendidikan modern.

Dari penjabaran tersebut jelas bahwa beliau tidak punya pengalaman pendidikan Barat, tapi beliau tetap memberi ruang bagi gerbang rasionalitas dalam ajaran Islam. Semangat rasionalitas ini tidak bisa lepas dari pengaruh gerakan pembaharuan yang dipahami sebagai pikiran, aliran, gerakan dan usaha "mengubah" ajaran-ajaran yang terdapat dalam agama untuk disesuaikan dengan konteks baru yang ditimbulkan oleh kemajuan iptek.

\section{DAFTAR PUSTAKA}

Ch, Nasruddin Anshoriy. 2010. Matahari Pembaruan. Yogyakarta: Jogja Bakti Publisher.

Damami, Muhammad. 200o. Akar Gerakan Muhammadiyah. Yogyakarta: Fajar Pustaka Baru.

FajlurRahman Jurdi, Aib Politik Muhammadiyah, (Cet. I; Yogyakarta: Juxtapose, 2007)

Hambali Hamdan, Ideologi Dan Strategi Muhammadiyah. Cet. IV; Yogyakarta: Suara Muhammadiyah, 2008

Majelis Diklitbang dan LPI PP Muhammadiyah. 2010. 1 Abad Muhammadiyah: Gagasan Pembaruan Sosial Keagamaan. Jakarta: Kompas.

Malik, Maman A. dkk. 2005. PengantarSejarah Kebidayaan Islam. Yogyakarta: Pokja Akademik UIN Sunan Kalijaga Yogyakarta. 
Mulkhan, Abdul Munir. Kiai Ahmad Dahlan: Jejak Pembaruan Sosial dan Kemanusiaan. Jakarta: Kompas, 2010 Marhaenis Muhammadiyah. Cet. I; Yogyakarta: Galangpress, 2010

Moertiyah, GRAy, Koes. Satu Abad Muhammadiyah: Tafsir Jawa Keteladanan KIAI Ahmad Dahlan. Yogyakarta: Adiwacana, 2013

Nasution, Harun. 2003. Pembaharuan dalam Islam: Sejarah Pemikiran dan Gerakan. Jakarta: Bulan Bintang.

Nugroho, M. Yususf Amin. 2012. "Fiqh Al-Ikhtilaf NU-Muhammadiyah" (e-Book). Wonosobo: tanpa penerbit.

Nur Achmad \& Pramono U. Tanthowi, ed, Muhammadiyah Digugat. Cet. I; Jakarta: PT Gramedia, 2000

Percetakan Muhammadiyah, Berita Resmi Muhammadiyah: Tanfidz Keputusan Muktamar Satu Abad Muhammadiyah ke 46. Yogyakarta: Percetakan Muhammadiyah, 2010.

Shodiqin, Mochammad Ali. 2013. Muhammadiyah itu NU: Dokumen Fiqh yang Terlupakan. Yogyakarta: Noura Books.

Simbolon, Oarakitri T. 2006. Menjadi Indonesia. Jakarta: Kompas.

Soeratno, Siti Chamamah, dkk. Muhammadiyah Sebagai Gerakan Seni dan Budaya: Suatu Warisan Intelektual yang Terlupakan. Cet. I; Yogyakarta: Pustaka Pelajar, 2009

Suwarno, Muhammadiyah Sebagai Oposisi. Cet. I; Yogyakarta: UII Press Jogjakarta, 2001

Zuhairini, dkk. 2011. Sejaran Pendidikan Islam. Jakarta: Bumi Aksara.

Ahmad, Fandi. "Pemikiran KH Ahmad Dahlan Tentang Pendidikan Dan Implementasinya Di SMP Muhammadiyah 6 Yogyakarta Tahun 2014/2015." Profetika: Jurnal Studi Islam 16, no. 2 (2015): 144-54.

Arofah, Siti. "Gagasan Dasar Dan Pemikiran Pendidikan Islam KH Ahmad Dahlan." Tajdida: Jurnal Pemikiran Dan Gerakan Muhammadiyah 13, no. 2 (2016): 114-24.

Mustapa, Leyan. "Pembaruan Pendidikan Islam: Studi Atas Teologi Sosial Pemikiran KH Ahmad Dahlan.” Jurnal Ilmiah AL-Jauhari: Jurnal Studi Islam Dan Interdisipliner 2, no. 1 (2017): 90-111. 